\title{
ESSAY:
}

\section{AN INTRODUCTION TO THE}

\section{LAW OF COPYRIGHT}

\section{DINAL PHILIPS ${ }^{1}$}

\section{Abstract}

'Copyright' is a very much interested, but not comprehensively resolved topic in both legal and library professional arenas. This paper simply describes types of works protected by copyright, standards, procedure for getting protection, infringement, duration of rights, and international protection for the benefit of librarians specially with respect to the Sri Lankan context.

Keywords: Copyright, Interlectual property, Copyright infringement

\section{Introduction}

Bill Gates has said that Intellectual Property (IP) has the shelf life of a banana. This might be true about some type of IP rights but when it comes to Copyrights it can last for much longer and be relevant for up to a few generations.

Copyright law in Sri Lanka is based on the Intellectual Property Act No 36 of 2003, an Act of Parliament enacted to preserve and recognize Intellectual Property rights in the Country. I'll refer to this statute throughout the speech as the IP Act. Part II of the Act contains provisions regarding Copyright.

\footnotetext{
${ }^{1}$ Mr. Dinal Philips - Attorney at Law \& a specialist in Intellectual Property - delivered his presentation 'Copyright for information trade' at the 'Partners in Information Delivery' seminar organized by the University Librarians Association (ULA) of Sri Lanka held on 26 September 2008 at BMICH, Colombo 7. This is the text of his speech.
} 
This Act seeks to protect several Intellectual Property rights including Trade Marks, Patents and of course copyright.

Copyright law is important for Authors and publishers for two reasons:

- $\quad$ Original works are protected by copyright. The IP Act's exclusive rights provision gives authors and publishers the right to control unauthorized exploitation of their works.

- Works are created by combining "content" - music, text, graphics, illustrations, photographs, software - that is protected under copyright law. Authors and publishers must avoid infringing copyrights owned by others.

\section{Types of Works Protected by Copyright}

Copyright law protects "works of authorship." The IP Act states that works of authorship include the following types of works:

- Literary works. Novels, non-fiction prose, poetry, newspaper articles and newspapers, magazine articles and magazines, computer software, software documentation and manuals, training manuals, manuals, catalogs, brochures, ads (text), and compilations such as business directories

- $\quad$ Musical works. Songs, advertising jingles, and instrumentals.

- $\quad$ Dramatic works. Plays, operas, and skits.

- $\quad$ Pantomimes and choreographic works. Ballets, modern dance, jazz dance, and mime works.

- $\quad$ Pictorial, graphic, and sculptural works. Photographs, posters, maps, paintings, drawings, graphic art, display ads, cartoon strips and cartoon characters, stuffed animals, statues, paintings, and works of fine art. 
- Motion pictures and other audiovisual works. Movies, documentaries, travelogues, training films and videos, television shows, television ads, and interactive multimedia works.

- $\quad$ Sound recordings. Recordings of music, sounds, or words.

- Architectural works. Building designs, whether in the form of architectural plans, drawings, or the constructed building itself.

\section{Standards}

To receive copyright protection, a work must be "original" and must be "fixed" in a tangible medium of expression. Certain types of works are not copyrightable.

\subsection{Originality}

The originality requirement is not stringent: $\mathrm{A}$ work is original in the copyright sense if it owes its origin to the author and was not copied from some preexisting work. A work can be original without being novel or unique.

Example: A book on How to be a Millionaire is original in the copyright sense so long as he Author did not create the book by copying existing material - even if it's the millionth book to be written on the subject.

Only minimal creativity is required to meet the originality requirement. No artistic merit or beauty is required.

A work can incorporate preexisting material and still be original. When preexisting material is incorporated into a new work, the copyright on the new work covers only the original material contributed by the author.

Example: Developer's multimedia work incorporates a number of photographs that were made by Photographer (who gave Developer permission to use the photographs in the multimedia work). The multimedia work as a whole owes its origin to Developer, but the photographs do not. The copyright on the 
multimedia work does not cover the photographs, just the material created by Developer.

Facts owe their origin to no one and so are not original. A compilation of facts (a work formed by collecting and assembling data) is protected by copyright only to the extent of the author's originality in the selection, coordination, and arrangement of the facts.

Example: If a person created a neighbourhood phone directory for his neighbourhood by going door-to-door and getting his neighbours' names and phone numbers. The directory's facts (names and phone numbers) are not original. Ralph's selection of facts was not original (he "selected" every household in the neighbourhood). His coordination and arrangement of facts (alphabetical order by last name) is routine rather than original. The directory is not protected by copyright.

\subsection{Uncopyrightable Works}

Works prepared by government officers and employees as parts of their official duties are not protected by copyright. Consequently, statutes (the IP Act, for example) and regulations are not protected by copyright. This rule does not apply to works created by government officers and employees during their own free time.

The design of a useful article is protected by copyright only if, and to the extent that, the design incorporates pictorial, graphic, or sculptural features that can be identified separately from, and are capable of existing independently of, the utilitarian aspects of the article. For example, while a "normal" belt buckle is not protected, a three-dimensional belt-buckle design with a dolphin shape qualifies for limited protection.

Uncopyrightable works and works for which copyright protection has ended are referred to as "public domain" works. This is because a work in Sri Lanka is 
Copyrightable for only 70 years after the death of the Author. Afterwards the public is free to use them as they wish.

\section{Procedure for Getting Protection}

Copyright protection arises automatically when an original work of authorship is fixed in a tangible medium of expression.

\subsection{The Exclusive Rights}

A copyright owner has five exclusive rights in the copyrighted work:

i. Reproduction Right. The reproduction right is the right to copy, duplicate, transcribe, or imitate the work in fixed form.

ii. Modification Right. The modification right (also known as the derivative works right) is the right to modify the work to create a new work. A new work that is based on a pre-existing work is known as a "derivative work."

iii. Distribution Right. The distribution right is the right to distribute copies of the work to the public by sale, rental, lease, or lending.

iv. Public Performance Right. The public performance right is the right to recite, play, dance, act, or show the work at public place or to transmit it to the public. In the case of a motion picture or other audiovisual work, showing the work's images in sequence is considered "performance."

v. Public Display Right. The public display right is the right to show a copy of the work directly or by means of a film, slide, or television image at a public place or to transmit it to the public. In the case of a motion picture or other audiovisual work, showing the work's images out of sequence is considered "display." 


\section{Infringement}

Anyone who violates any of the exclusive rights of a copyright owner is an infringer.

Example: Developer scanned Photographer's copyrighted photograph, altered the image by using digital editing software, and included the altered version of the photograph in a multimedia work that Developer sold to consumers. If Developer used Photographer's photograph without permission, Developer infringed Photographer's copyright by violating the reproduction right (scanning the photograph), the modification right (altering the photograph), and the distribution right (selling the altered photograph as part of the multimedia work).

A copyright owner can recover actual or, in some cases, statutory damages from an infringer. The Commercial High Court has the power to issue injunctions (orders) to prevent or restrain copyright infringement and to order the impoundment and destruction of infringing copies.

\section{Duration of the Rights}

As mentioned above under current law, the copyright term for works created by individuals is the life of the author plus 70 years.

\subsection{Limitations on the exclusive rights}

The copyright owner's exclusive rights are subject to a number of exceptions and limitations that give others the right to make limited use of a copyrighted work. Major exceptions and limitations are outlined in this section.

\subsubsection{Ideas}

Copyright protects only against the unauthorized taking of a protected work's "expression." It does not extend to the work's ideas, procedures, processes, systems, methods of operation, concepts, principles, or discoveries. 


\subsubsection{Facts}

A work's facts are not protected by copyright, even if the author spent large amounts of time, effort, and money discovering those facts. Copyright protects originality, not effort or "sweat of the brow."

\subsubsection{Independent Creation}

A copyright owner has no recourse against another person who, working independently creates an exact duplicate of the copyrighted work. The independent creation of a similar work or even an exact duplicate does not violate any of the copyright owner's exclusive rights.

\subsubsection{Fair Use}

The "fair use" of a copyrighted work, including use for purposes such as criticism, comment, news reporting, teaching, scholarship, or research, is not an infringement of copyright. Copyright owners are, by law, deemed to consent to fair use of their works by others.

Fair use is difficult to define and so the following:

An intellectual property attorney at a large New York law firm turned 40 and had a midlife crisis. He resigned his senior partnership and began to travel the world in search of enlightenment.

While in India, he heard about a holy man, a guru, who had been sitting on the top of a mountain in deep meditation continuously for a very very long time. The former attorney went to the top of the mountain, sat down in full lotus position across from the guru and began to meditate.

After several days the former attorney couldn't stand it any more, opened his eyes and said loudly to the guru: "oh great Master, what is the meaning of life?" The guru then opened his eyes and said: 
"life, schmif, what I want to know is, what is the meaning of 'fair use?""

The IP Act describes fair use in sections 11 and 12. Factors such as

- The purpose and character of the use.

- $\quad$ The nature of the copyrighted work.

- The amount and substantiality of the portion used in relation to the copyrighted work as a whole.

- The effect of the use on the potential market for, or value of, the copyrighted work.

are considered when determining fair use.

\section{International Protection}

Authors automatically receive copyright protection in all countries that are parties to the Berne Convention for the Protection of Literary and Artistic Works, or parties to the Universal Copyright Convention (UCC). Most countries belong to at least one of these conventions. Members of the two international copyright conventions have agreed to give nationals of member countries the same level of copyright protection they give their own nationals.

Example: Publisher has discovered that bootleg copies of one of its multimedia works are being sold in England. Because the United Kingdom is a member of the Berne Convention and the UCC, Publisher's work is automatically protected by copyright in England. When Publisher files a copyright infringement action in England against the bootlegger, Publisher will be given the same rights that an English copyright owner would be given.

Works of foreign authors who are nationals of Berne or UCC- member countries automatically receive copyright protection in Sri Lanka, as do works first published in a Berne Convention or UCC country. 